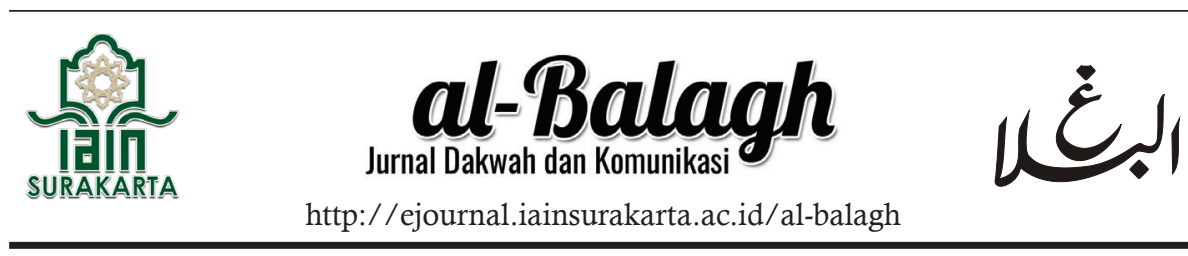

\title{
DISABILITY AND SOCIAL MEDIA: EXPLORING UTILIZATION OF INSTRAGRAM PLATFORM AS A TOOL FOR DISABILITY ADVOCACY
}

\author{
Ani Cahyadi* \\ Universitas Islam Negeri (UIN) Antasari Banjarmasin \\ Agus Setiawan \\ Institusi Agama Islam Negeri (IAIN) Samarinda
}

\begin{tabular}{l}
\hline Keywords: \\
accessibility; \\
advocacy; disability; \\
Instagram; social \\
media; technology
\end{tabular}

Correspondence:

e-mail: *anicahyadi@uin-antasari.ac.id agus.setiawan@iain-samarinda.ac.id

\begin{abstract}
Social media such as Instagram has been a tool to facilitate subjective interests of its users, either individually or collectively. Furthermore, Instagram is an effective campaign and advocacy tool for issues like disability and inclusiveness. Therefore, this study aims to explore how this platform is used as an advocacy tool for the disabled and its relation with disability advocacy from the phenomenological approach. The respondents in this study were two actors with disabilities, while the informants were four individuals from the Banjarbilitas group that care about disabilities. Data analysis was carried out using the Social Model of Disability. The discoveries of this study lead to two main points. Firstly, Instagram as a new social media, has transformed into an important networking platform, which provides opportunities for the disabled to advocate and negotiate their existence and that of their groups in relation to equality in society. Secondly, it has provided them with basic access to job vacancies, freedom to express themselves, connect with other individuals and share information and most significantly the opportunity to facilitate both their personal and group interest in order to increase their prosperity and accessibility progressively and comprehensively.
\end{abstract}




\begin{tabular}{l}
\hline \\
\hline Kata kunci: \\
aksesibilitas; \\
advokasi; \\
disabilitas; \\
Instagram; media \\
sosial; teknologi
\end{tabular}

\section{How to cite this (APA 7th Edition):}

Cahyadi, A. \& Setiawan, A. (2020). Disability And Social Media: Exploring Utilization Of Instragram Platform As A Tool For Disability Advocacy. Al-Balagh: Jurnal Dakwah Dan Komunikasi, 5(2), 223-250. https://doi. org/10.22515/al-balagh.v5i2.2746

\begin{abstract}
Abstrak
Instagram sebagai media sosial, telah menjadi alat yang dianggap mampu memfasilitasi kepentingan-kepentingan subyektif oleh penggunanya, baik kepentingan yang bersifat individu maupun kelompok. Selain itu, Instagram juga berfungsi sebagai alat yang dinilai efektif untuk kampanye dan mengadvokasi berbagai hal, seperti isu disabilitas dan inklusivitas. Paper ini bertujuan untuk menggambarkan pemanfaatan media sosial Instagram sebagai alat advokasi isu disabilitas serta pertautan antar keduanya. Penelitian ini menggunakan pendekatan fenomenologi, dan pisau analisisnya menggunakan teori Social Model of Disability. Responden penelitian ini ada dua orang dari kalangan disabilitas, sedangkan informan dalam penelitian ini sebanyak empat orang, yaitu kelompok banjaribilitas yang peduli terhadap disabilitas. Hasil penelitian ini berisi dua poin penting. Pertama, Instagram telah bertransformasi menjadi sebuah jejaring yang berperan penting dalam memberikan ruang bagi hak-hak penyandang disabilitas untuk mengadvokasikan dan menegosiasikan eksistensi diri maupun kelompoknya tentang kesetaraan ke masyarakat arus utama. Kedua, Instagram telah memberikan akses dasar bagi penyandang disabilitas seperti; lowongan pekerjaan yang memadai, kebebasan dalam mengekspresikan diri, menjalin hubungan, berbagi informasi dan yang paling signifikan adalah kemampuannya menjadi sebuah media alternatif dalam memfasilitasi kepentingan-kepentingan pribadi dan kelompok untuk meningkatkan kesejahteraan dan aksesibilitas indvidu dengan bertahap secara keseluruhan.
\end{abstract}

\section{INTRODUCTION}

In this era of digitalization, the social media platform has grown rapidly from private online meeting room to public forum filled with 
several discourses. Most social media platforms in the past decade have shifted significantly in terms of the services provided to the users. The creators of social media-based apps have developed several features that are accessible by users, making them a public space for many. These rooms occasionally become a place for critical discussion about international events, local issues, activism and others (Gleason et al., 2019). Digitalization era also known as disruption era, is an era where all human activities involve a disruptive context (KBBI Online, 2020). This era has entirely transformed social activities which merely take place in real world into digital world (Ananda, 2018). Presently, media digitalization has transformed the social structure which was previously dependent on face to face static interaction into timeless mobile interaction and has affected all groups in the society including minority groups, such as the disabled (Salim, 2015a; Salim, 2015b). In studies on disability, there has been a lot of discussion on several things, such as various disability theories/models, dynamics, movements, political contestation and ideology, to the various perspectives that follow (Amin, 2019). Therefore, it is interesting to further discuss and explore the issue of social media as a new movement in disability studies.

The digital era has assisted the disabled to no longer depend solely on street demonstration and similar actions in order to negotiate their selfexistence or that of their group to the society like what have been earlier carried out by their fellow disabled activists with social inclusiveness movement. However, the virtual world engenders both opportunities and challenges for the disabled (Ellis \& Kent, 2011). Meanwhile, limitless access to available social media has assisted them to advocate their selves through digital rooms and platforms, which are now widely open to every individual. 
Some studies which focused on disabilities have been previously carried out by scholars and researchers, such as the study by Caton \& Chapman (2016), which showed that individuals with intellectual disabilities have encountered positive experiences in terms of friendship, development of social identity and self-esteem as well as enjoyment, while using the social media. Mcmillen \& Alter (2017), also showed that social media has a positive impact on the disabled especially in relation to social inclusion. Furthermore, the discoveries of Sweet, LeBlanc, Stough, \& Sweany (2020) are very important in understanding how the media are used by the disabled, because it is a flexible tool both in formal and informal education. Caron \& Light (2016) found it interesting that social media is a useful tool as well as an important form of communication and is usable as in active learning on social media. In addition, Gleason et al., (2019) revealed that social media is an important issue that has become a challenge for researchers and practitioners in relation to its use and accessibility for the disabled.

In the Indonesian context, there has been a lot of studies related to social media and their relation with disability, such as the study by Rovasita (2017), which explored the benefits of a Facebook group as a means to gather and share among parents with Cerebral Palsy kids in a group named Orang Tua Anak Cerebral Palsy. It was explained that parents after discovering that their kids suffer from Cerebral Palsy tend to feel sorrowful, which leads to diffidence and desperation. According to Rovasita, this was due to low stress resilience. Therefore, the parents sought solutions to this, by building sense of acceptance within them, which was accommodated by sharing experiences in the group.

Furthermore, Rovasita argued that the Facebook group significantly improved the resilience of parents with Cerebral Palcy kids because they obtained valuable knowledge and information from that forum. In conclusion, it was stated that understanding Facebook as digital platform 
does not only assist general users in their communication, but also other individuals with the same problems to seek solution to it as they were willing to share valuable information with others to increase their understanding, self-acceptance and resilience to their problems.

Another study related to disability issue was that of Diana (2012), which described how Facebook was used by intellectually disabled teenagers in SOIna Rawamangun. The discussion covered the role of Facebook as source of information, reason and purpose for its usage, ways and kinds of Facebook utilization, interaction pattern, language usage, utilization intensity and impacts of its utilization to teenagers. This study discovered that Facebook as social network was used by teenagers to advocate and negotiate their selves to friends of same age group and their environment. In addition, it was useful in improving their language and social interaction. Azizah \& Rahmatika (2019) also argued that there is a significant positive correlation between the use of gadgets and satisfaction of interpersonal communication at UIN Sunan Kalijaga disabilities.

Furthermore, another interesting study was carried out by Mamase, Mohidin, \& Hulopi, (2018), where they recommended an Android based application to assist the deaf and blind. Therefore, the difficulties and differences in how they communicate became the main focus in order to ease communication between them. In this study, the phases of using the application in detail were also explained.

Many of the available literature has discussed about social media utilization and their relation with disability issues. However, there has been no study which specifically discussed the use of Instagram as an advocacy tool for individuals with disabilities. Therefore, in the light of these literature reviews and significance of further exploration and development of such discourse, it is then necessary to carry out this study. 


\section{METHODS}

This study focused on exploring Instagram application as a tool for disability advocacy and the relationship between both, using a phenomenological approach. The respondents of this study were two actors with disabilities, while the informants were four individuals namely the Banjarbilitas group that care about disabilities. These respondents were selected using purposive sampling technique, in which the selection process was carried out purposively based on the categories and characteristics intended. The primary and secondary data were collected by exploring the phenomena or news published on either articles, books or social media, Instagram in particular. Furthermore, data analysis was carried out using Social Model of Disability.

\section{RESULTS AND DISCUSSION}

In this sub-discussion, the results from the exploration of the use of Instagram as an advocacy tool were described. Furthermore, the different advocacy methods applied by individuals with disabilities by maximizing Instagram as a tool to achieve social inclusion were described as well.

\section{Work Advocacy And Current Disabled Communities}

In the digital era, advocacy is supported by numerous platforms available in today's social media. Various social media have been utilized by many individuals with different backgrounds, including the community of those with disabilities.

Instagram, since some years ago, has been used by a lot of individuals to optimize their activities. As a new social media, it has transformed quickly into a medium that does not only accommodate the subjective interest of the user, but broader collective interest as well. Regarding work advocacy, a lot of platforms have provided opportunities for the disabled, 
which are accessible online, primarily through Instagram. However, to focus on this discussion, two kinds of work platforms were explored, namely Kerjabilitas and Thisabel Enterprise.

\section{Kerjabilitas}

Presently, Kerjabilitas is the most exciting job vacancy platform for the disabled in Indonesia, which was made known two years ago through an Instagram account, @Kerjabilitasid. It is the first program carried out by Saujana, with the aim of reaching, training and placing individuals with disabilities in the work world. This program, according to Saujana's site, started in March, 2015, when Kerjabilitas.com was officially launched online. Furthermore, it plays a significant role as a reach out channel as well as job provider for job seekers with disability (Saujana, 2020).

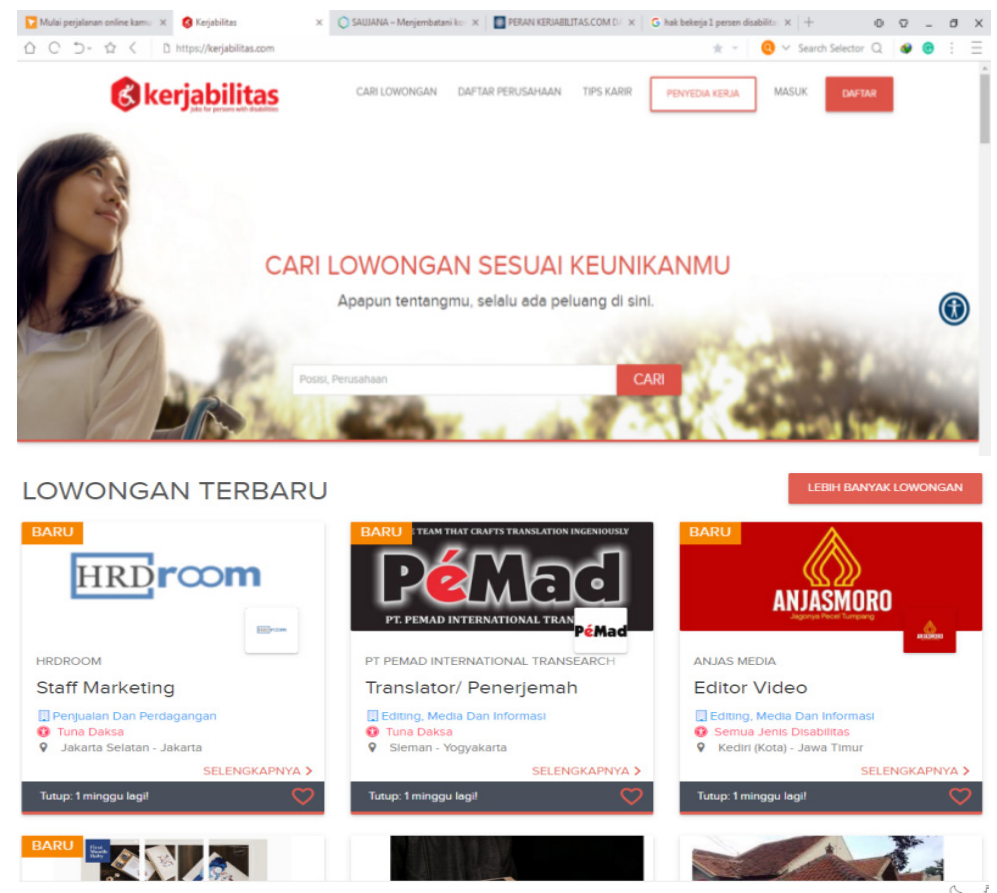

Figure 1. Visualization of official blog of kerjabilitas.com (Source:

$$
\text { https://kerjabilitas.com) }
$$


Kerjabilitas.com, based on its profile description, is a carrier social network that connects individuals with disabilities to inclusion job providers in Indonesia. Furthermore, it is a website and cellular softwarebased information system that connects work seekers with disabilities to employment providers. Through the availability of this information system, individuals with disabilities are able to place their profile as job seekers and access information on job vacancies available for them.

In addition, it supports employment service providers to provide opportunities for the disabled as well as fulfill a duty promised by law that companies should hire them. Besides the availability of job information and communication forum, Kerjabilitas.com also incorporates various contents, such as visual, audio and video presentation of life skills and self-development to assist the disabled in upgrading their skills in the work world competition. This content is always been developed and renewed periodically. Furthermore, at Kerjabilitas.com, individuals with disabilities are not only able to search jobs but also express their opinions in a communication forum related to issues in their neighborhood (Kerjabilitas, 2020).

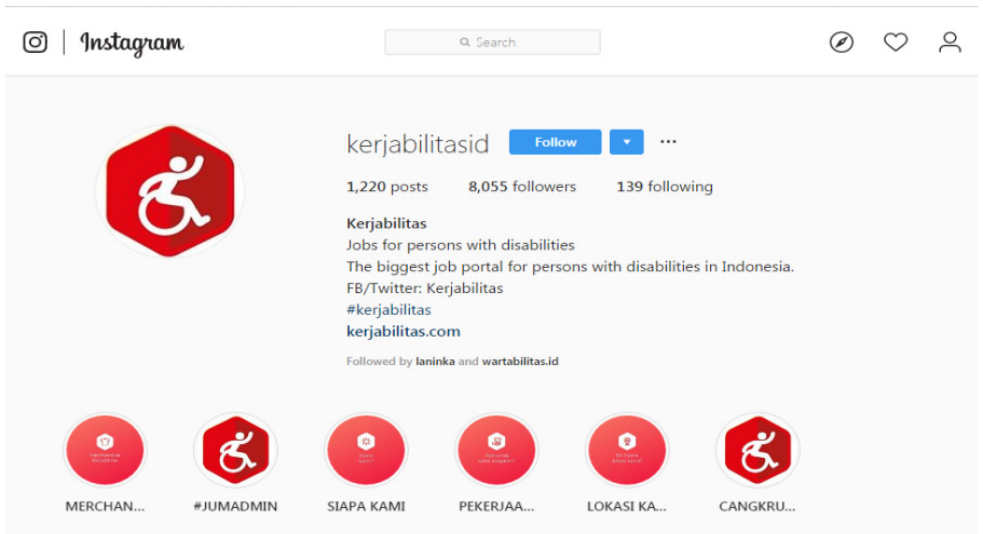




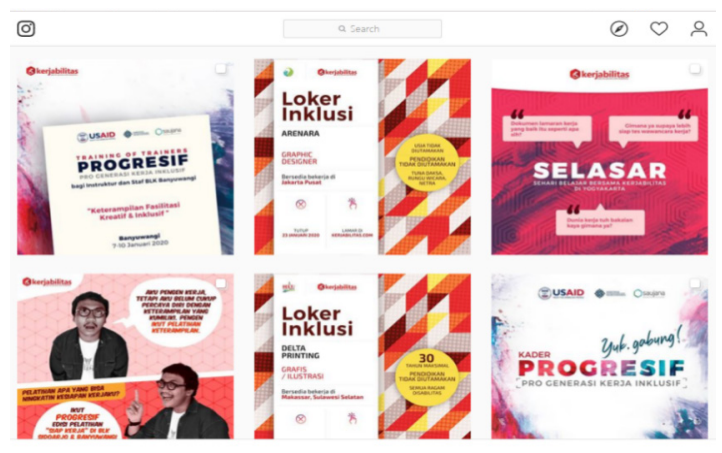

Figure 2. Visualization oftheInstagramofficialaccountof@Kerjabilitasid.

(Source https://www.instagram.com/kerjabilitasid/)

\section{Thisabel Enterprise And Characterization Of Angkie Yudistia}

Besides@kerjabilitasid, another digital Platform on Instagram that is related to job vacancy for individuals with disabilities is@thisabel.id (Thisabel Enterprise). Thisable Enterprise is an official social enterprise built in 2011 with a mission to economically empower the disabled in Indonesia in the work world (Thisable Enterprise, 2018). Similar to@kerjabilitasid, the@, thisable.id was discovered two years ago (since the commencement of this study) while browsing literature to enrich the study data on disability advocacy in social media in 2018.

Thisabel Enterprise was built by one of the females with disabilities, named Angkie Yudistia. As quoted from Tempo.co, this social enterprise was created to grant individuals with disabilities job access and empower them. Currently, there are companies that are ready to employ them on a need basis (Ningsih, 2018). Therefore, this enterprise has developed into a group leading Thisable foundation, Recruitment and Digital. Through these companies, Angkie holds training for disabled human resources in order to assist them work vocationally and professionally. In 2017, Thisable Enterprise invited Go-Jek to be their business partner, where those with disabilities led by Thisable Enterprise were distributed as employees for 
Al-Balagh: Jurnal Dakwah dan Komunikasi,

Vol. 5, No. 2, July - December 2020, pp. 223 - 250, DOI: https:// doi.org/10.22515/al-balagh.v5i2.2746 ISSN: 2527-5704 (P) ISSN: 2527-5682 (E)

some Go-Jek services, such as Go-Massage, Go-Clean, Go-auto and GoGlam, based on their individual skills.

Thisable Enterprise also launched some retail products, especially body treatment, such as soap and beauty cosmetics. Therefore, the name Angkie once became a trending topic on many newspapers, social media and other digital media after her appointment by President Joko Widodo as a special staff of the President. Furthermore, as the spokesperson for the President in social field, as a representation of top achiever millennial with disabilities (Perwitasari, 2019).

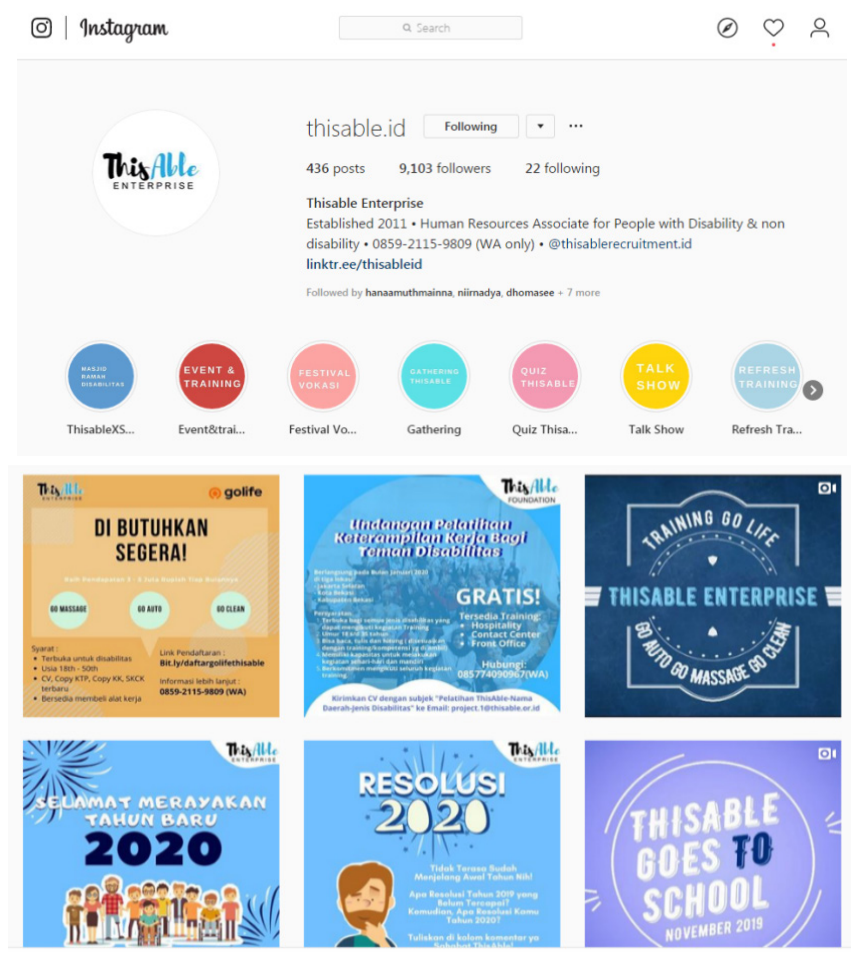

Figure 3. Visualization of the Instagram official account of @ thisable.id. (Source https://www.instagram.com/thisable.id/)

From the visualization of the Instagram official account of @ kerjabilitasid and@thisable.id, the process by which Instagram as a social 
media platform has been recently used as a medium to socialize or advocate job vacancies for easy access by the disabled is seen. In both accounts, there are a lot of interesting job vacancies available for them, which is easily and freely accessible on the basis of their passions and abilities. Although, both platforms have official accounts on all social media platforms, Instagram greatly contributes to socialize the available job vacancies. This is because, as a new social medium, it has become an application used by all levels of society. Therefore, it is able to facilitate socialization process and work advocacy for the disabled.

\section{Negotiating Self And Groups Towards Social Inclusion}

Negotiating self into a particular group urgently requires high motivation, both intrinsically and extrinsically. However, high motivation sometimes requires the support of the media or tools, either to accelerate acceptance or strengthen the existence of the self and negotiated group. Therefore, some important points need to be explained regarding advocacy and negotiation carried out by the disabled using Instagram towards inclusive society.

Accordingly, an individual with a disability named Lalinka Siamiyono that has an Instagram account @laninka was described. Laninka suffers from Rheumatoid Arthritis (an autoimmune medical problem that causes joint inflammation leading to stiffness of the hand and leg), which physically includes her in the category of the disabled. Consequently, she has been using a wheelchair for daily activities since she was 15 years of age. Nevertheless, she was able to rise and discover her confidence again through a makeover and inspire others through her YouTube channel and Instagram account (Mayasari, 2018).

Some of the posts uploaded on her Instagram account are always related to beauty and focuses on women with disabilities. On her Instagrambiography, Laninka wrote "Makeup is my therapy "and 
Al-Balagh: Jurnal Dakwah dan Komunikasi,

Vol. 5, No. 2, July - December 2020, pp. 223 - 250, DOI: https://doi.org/10.22515/al-balagh.v5i2.2746

ISSN: 2527-5704 (P) ISSN: 2527-5682 (E)

"Beauty Enthusiast with disabilities". This biography explains that she considers makeup as her therapy and focuses on beauty for individuals with disabilities. Furthermore, she is the founder of @lipstikuntukdifabel and@uniqueband_which focuses on beauty issues. In Instagram, there are more than 100 posts that use the hashtag \#lipstikuntukdifabel. This shows the personal enthusiasm of the disabled on this issue. Furthermore, she personally advocates disability groups in beauty act, which is an antimainstream issue rarely discussed in the study of disability, especially in the context of Indonesia.
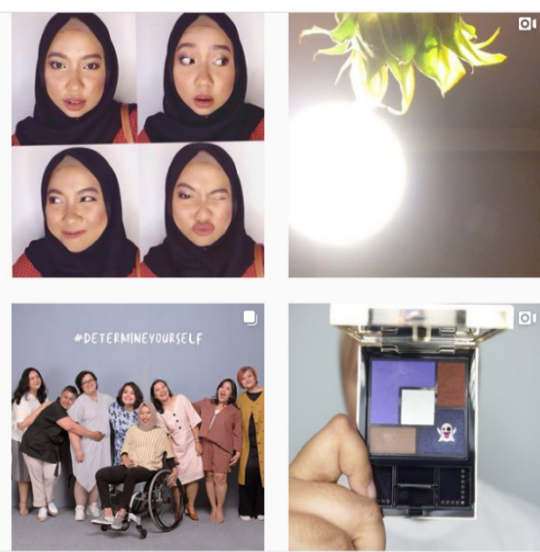
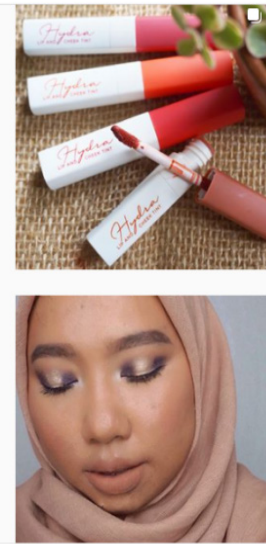
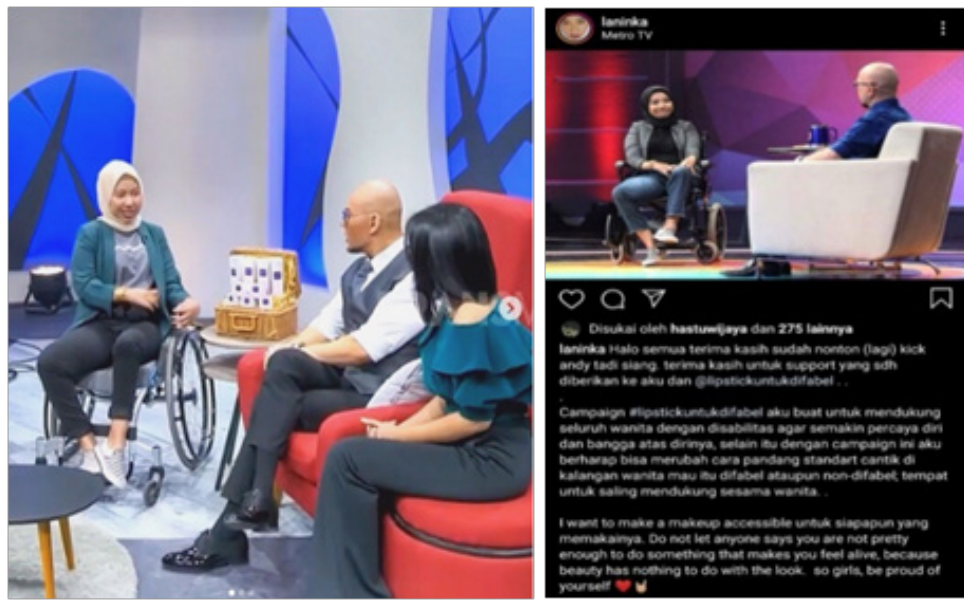

Figure 3. Visualisation from (Source: https://www.instagram.com/ laninka/) 
From the visualization of the Instagram account above, it is seen that Lalinka's concern on disability and beauty issues made her an icon in this issue. She appears to be capable of advocating and negotiating personally and in groups through her Instagram account. Furthermore, from her posts it is seen that she was invited to popular talkshows in Indonesia, such as Kick Andi Show and HitamPutih.

It is also interesting to observe at the captions below her post, which show her presence in the Kick Andy Show talkshow, where she explained that "I made the \#lipstikuntukdifabel campaign to support all women with disabilities to be more confident and proud of themselves. Furthermore, with this campaign, it is hoped that the perspective of individuals on beauty standard would change, whether disabled or not, in order for women to support each other.'(Siamiyono, 2020)

From Laninka's statement above, an organized movement to advocate beauty issues among women with and without disabilities is seen. \#lipstikuntukdifabel is a movement made to increase self-confidence and pride among the disabled that have often been stigmatized by the society due to their disabilities. Through this movement, Laninka tried to surpass the stigma by building a positive construction and prioritizing the ability of the disabled to exist in social activities where beauty is the issue.

In addition, it is impressive to read the results of some interview carried out in this study with several informants regarding Instagram's role as their advocacy tool. For example, an MSN informant (initials) with physical disability stated that the accessibility to social media today has made it easier for individuals to advocate for themselves and their groups. An example is seen in the explanation below:

"For me, there are many things, such as visiting friends, searching for useful knowledge, discovering information, making more friends and most importantly, the social media can be used as a tool to advocate our organization to the 
public. Furthermore, with social media, especially Instagram, it is possible to advocate the organization and activities carried out, especially the events of Indonesia Association of Women with Disabilities (HWDI) to the public.” (MSN, 2019).

This is in line with the data obtained from an interview with a blind young man, with initials $\mathrm{HN}$, that is active on the Instagram. He advocates himself as a productive blind individual. Unlike other informants, he requested for neither his name to be mentioned nor photo to be used in this study.

Similar to what has been explained by the informants, HN (initials) stated that social media has always been accessible to the blinds, although some sites are still difficult to access. According to him, the social media has been of great assistance to him in obtaining information or content despite being blind. Instagram, according to him, is very useful to broaden his communication with the outside world, either with individuals with disabilities or not. Furthermore, he added that building the social media would assist in developing networks, broadening insight and increasing knowledge about world development, including disability issues ( $\mathrm{HN}$, 2019).

The above information points out to the fact that Instagram as a social medium has made a very significant contribution to people with disabilities. In addition to sharing information, it is also considered as a platform that facilitated the basic needs of the disabled, both individually and as a group. Individually, it has increased the opportunity to visit friends, access information and make new friends online as well as broaden online network. Meanwhile, as a group, it is an effective platform to introduce associations and share organizational agendas through Instagram feeds. This is very interesting because in this case, Instagram functions not only as an alternative media to advocate groups of individuals with disabilities, because previously, accessibility barriers were a very serious problem for disability organizations. 


\section{Sign Language As Deaf Culture}

Language is a very effective tool for communication both individually and in groups. Regarding sign language for the Deaf group, it is important to know that there are two sign language systems used in Indonesia. They include Sistem Isyarat Bahasa Indonesia, also known as SIBI and BISINDO which stands for Bahasa Isyarat Indonesia.

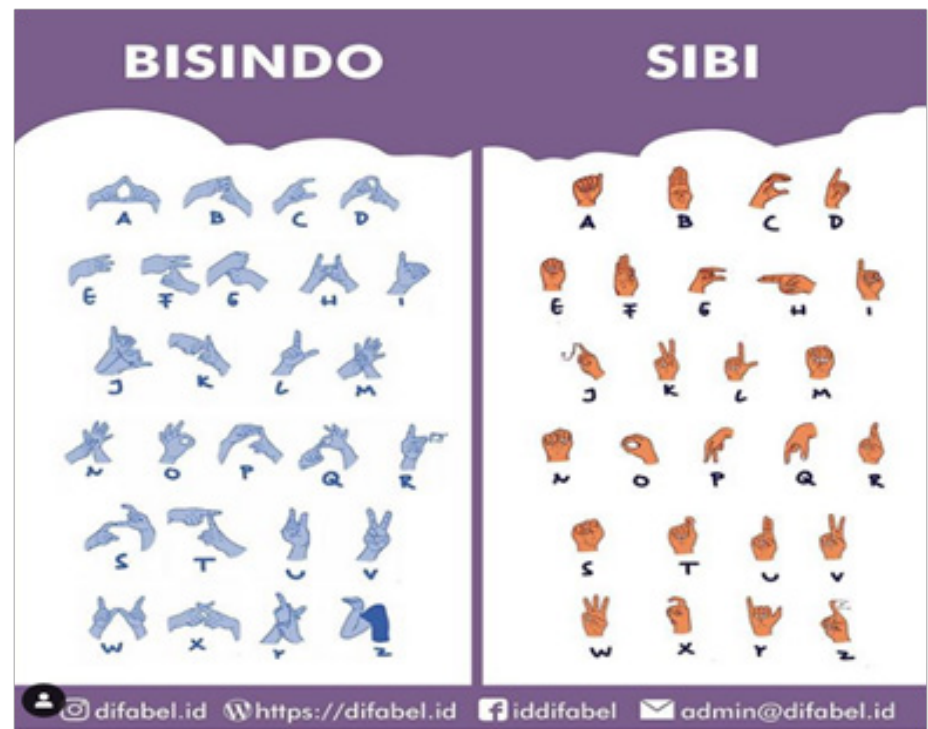

Figure 4. Figure of Sign Language (Source: difabel.id)

Although, there have been many debates over the two sign language systems above, many individuals recognize these two Indonesian sign language systems. Using personal accounts, it was possible to access approximately 11 thousand posts with hashtag \#bahasaisyarat (sign language) on Instagram. Furthermore, on posts related to SIBI alone, 18.1 thousand users used hashtag \#sibi, over 100 users used hashtag \#sibiindonesia and less than 100 users added hashtag \#bahasaisyaratsibi to their posts. Likewise with hashtags related to BISINDO, there were 82.8, 73.2 and 17.2 thousand posts with hashtag \#bisindoitukeren, \#bisindonesia and \#bisindo, respectively. 
From the few hashtags mentioned above, many were directly related to sign language. Meanwhile, there were 80.6 thousand posts with hashtag \#tuli, 12.4 thousand posts were for hearing impaired users and 803 thousand posts with hashtag \#deaf were globally posted.

Likewise, from the thousands of posts with hashtags above, many of them were directly related to the Deaf culture and the rests were related to the issue of inclusiveness in general. It is significant to narrow the discussion into two important points that are directly connected with the Deaf culture. Firstly, Instagram is used for social practices and secondly it is used as a manifestation of self and group negotiation towards social inclusion.

Furthermore, it was discovered that Instagram has been widely and freely used by many to practice sign language. Subsequently, there are a lot of Instagram users that are learning sign language from hearing-impaired individuals and practicing it in their daily activities. Most of these individuals are students studying in the Department of Special Education, volunteers at the disability service center, members of disability organizations or individuals that are interested to learn or explore sign language but are not willing to be attached to any kind of organization.

Besides, there are also individuals that have just started learning or learned either the SIBI or BISINDO systems from incidental events, practiced what they have learnt either regularly or occasionally and shared the videos of their practice through their Instagram accounts. The video contents are numerous, starting from self introduction using sign language, congratulating a special individual on special events, carrying out video covers using sign language, which by far are the most favoured video content by milineals. Furthermore, original singers in Indonesia participated in it. 

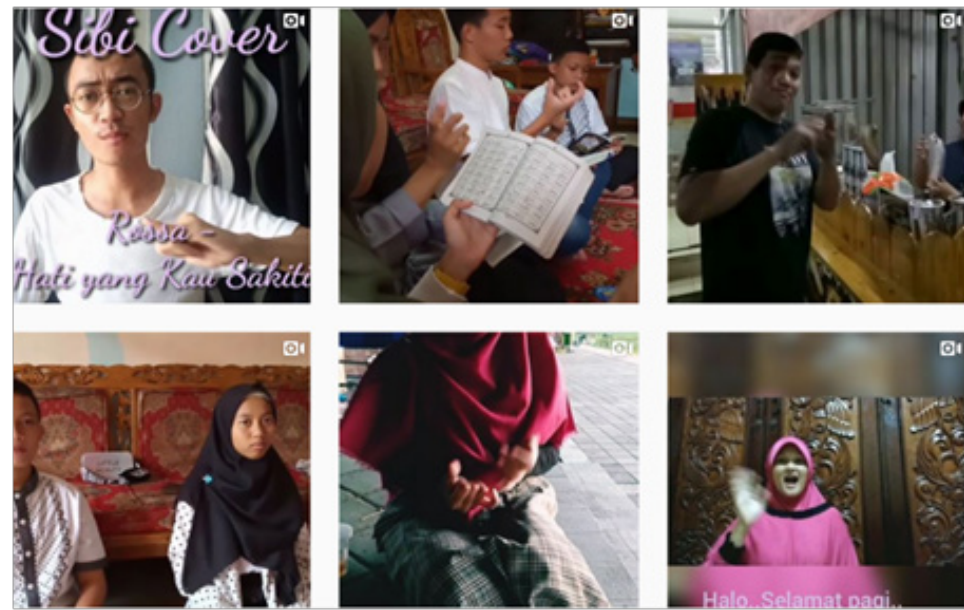

Figure 5. Sign Language Pratice (Source: https://www.instagram.com/ explore/tags/bahasaisyarat/)

The visualization above is what appears on Instagram when posts with hashtag \#bahasaisyarat are searched. They are videos of individuals using SIBI to cover a song and BISINDO in various activities. SIBI and BISINDO are identifiable by hand positions. This is because, SIBI tends to maximize the functions of single hand while BISINDO tends to maximize the functions of both hands. Although, there has been quite a debate on the style differences, however both languages are generally still developing.

Asides being sign language activists or just incidental learners, it is imperative to watch how Deaf people advocate for their accessibility or needs on Instagram accounts. Surya Sahetapi, for instance, is a Deaf individual that in many of his posts has tried to educate the public by explaining the problem he faces trying to access the mainstream media since they are mostly not accessible for the Deaf. In one of his posts, it is intriguing to see how he reviewed television shows with no subtitle. 

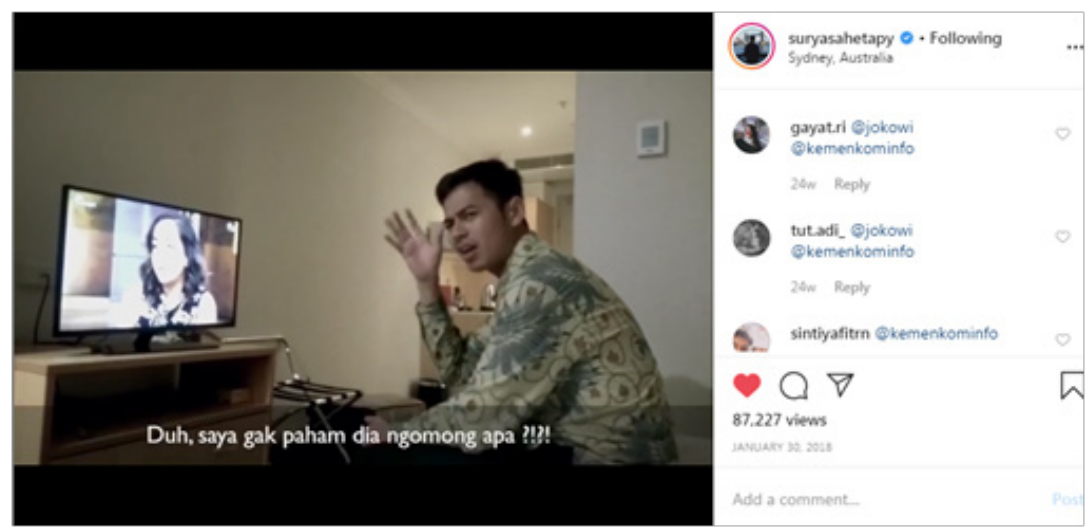

Figure 6. Surya Sahetapi Posted About Television With No Subtitle.

(Source: https://www.instagram.com/suryasahetapy/)

In the post that was uploaded three years ago above, on January 10 , 2018, Surya illustrates his difficulty in accessing a television show which does not have subtitles. He compared television shows in Sydney-Australia and those in Indonesia, stating that all TV stations in Australia have subtitles, different from those in Indonesia. Furthermore, as a Deaf, he hopes that all Indonesian TV stations display subtitles in order for them to be accessible and enjoyable to the Deaf in Indonesia as they would be able to reach information from news reports or enjoy entertainment available on TV stations. Law number 8 of 2016 has regulated the rights of the disabled in regards to accessibility (Law of the Republic of Indonesia Number 8 of 2016 concerning Persons with Disabilities, 2016). It requires TV stations as public facilities to be accessible to all citizen since it is the right of every citizen to have access to information of mainstream media. However, there have been very few TV stations which display subtitles on their shows. Some of them might have sign language interpreters, usually on the right-hand corner of the television screen, yet they are found solely on news reports or special events. 
Similar critique was also delivered by the account@annisa_ rahmania, where its user uploaded a video that illustrates the inclusiveness of television stations in Australia (Rahmania, 2019).
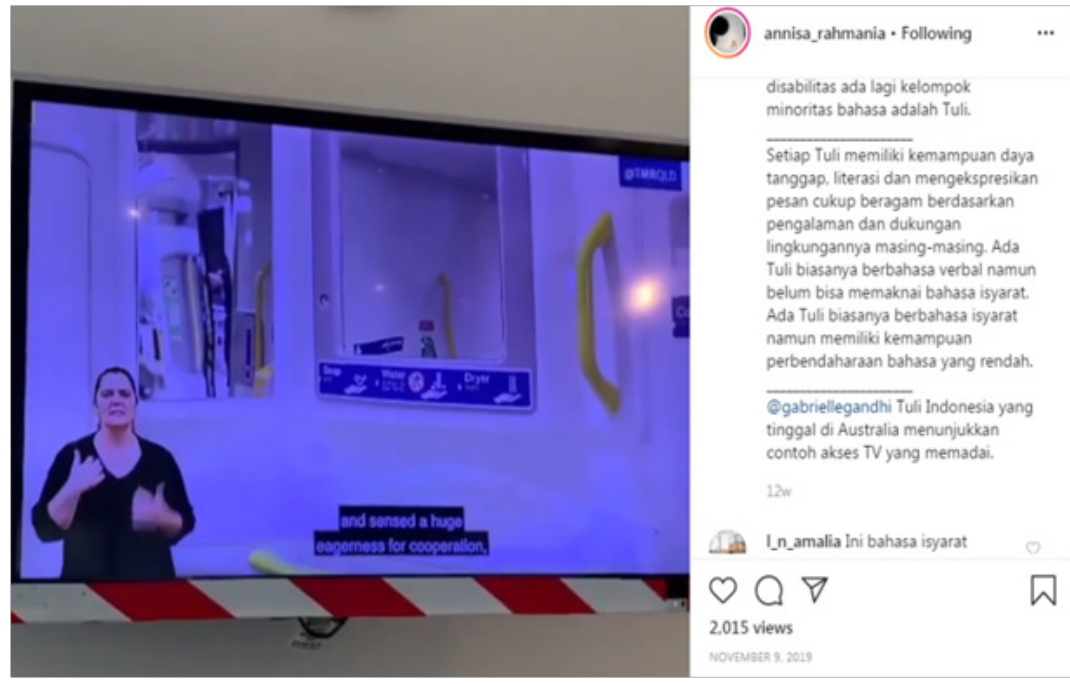

Figure 7. Television Stations In Australia With Subtitle (Source: https:// www.instagram.com/p/B4nxGOwgtrD/)

The above visualization shows a TV station in Australia which provided an example of adequate television access for the disabled, especially the Deaf. This was slightly different from what Surya has exemplified on Instagram. Therefore, Annisa showed television screen recordings which have more adequate visualization accessibility, using services of Sign Language Interpreters. In conclusion, it is very crucial to include subtitles or Sign Language Interpreters on TV screen visualization or other digital media to make it accessible to all levels of society.

\section{Media Digitalization And Its Benefits To Disabled Groups}

For many individuals, social media has become an integral part of their lives which has led to a greater sense of social inclusion (McMillen \& Alter, 2017). According to Sweet et al., (2020) social media most of the 
times involve many kinds of digital communication such as texts, pictures and videos where all users interact with each other to share information and others.

Social media usually involves networking sites such as Facebook, LinkedIn and Pinterest, microblogging tool like Twitter and Tumblr or sharing media such as Instagram and YouTube. Every kinds of tool enable its users to post information, interact with others and build online communities with shared interests. Consequently, contemporary conceptualization of "community" has evolved from the ones which require physical proximity for exchanges between individuals that have never been in contact face to face. Caton \& Chapman, (2016) seconded this notion by explaining that social media has become beneficial and plays an important role to support empowerment and participation of individuals and groups by activating the available social network. Furthermore, it increases self-esteem and enables online campaign between marginal groups, such as the disabled. Caron \& Light, (2016) added that presently, social media and network can be used by many groups in the society, either normal or disabled, to communicate their thoughts, share and collect information, maintain and develop relationship or develop social networking among users. In addition, Morey in his thesis explained that social media plays a significant role in the lives of humans, because they are used for communication and they affect relationship as well as prosperity of individuals in society as a whole (Morey, 2017).

\section{The Shift Of Disability Model Paradigm: Medical To Social}

Disability, or when directly referring to the disable-one, such an individual is said to be with disability, according to the Law Number 8 of 2016, is "everyone that undergoes physical, intellectual, mental and/or sensory disabilities. Consequently, in the long-term of their communication with the environment face obstacles and difficulties to participate entirely 
and effectively (in communities) as well as interact with others based on the same right" (Law of the Republic of Indonesia Number 8 of 2016 concerning Persons with Disabilities, 2016).

Regarding right to equality, The Convention on the Rights of Persons with Disabilities (CRPD) was adopted in 2006 and implemented in 2008, indicating the "paradigm-shift" from disability-oriented medical and traditional based approach to an issue relying on human right. The CRPD offers sufficient protection standards for civil, cultural, economic, political and social rights to the disabled based on inclusion, equality and non-discrimination norms. It is clear that the disabled have the right to independently live in the society, make their own choices and play active roles in the community (United Nations Human Rights Office The High Commisioner, 2018). Subsequently, in 2011, this policy was ratified in Indonesia and stated in the Law of the Republic of Indonesia, Number 19 of 2011 on Ratification of CRPD aiming at promoting, protecting and guaranteeing the fundamental equal right and freedom for all the disabled, as well as respecting their dignity as an integral part of society (Harahap \& Bustanuddin, 2015).

From the studies on disability, there have been a lot of discourses suggested by scholars which were later called theories or disability models. Every model or theory has a specific paradigm and different interpretation of disability. Those kinds of theories function to analyze or review the existing or developing phenomena in society.

In general, there are two developing models of approach or theories of disability in modern society. The first is the Medical Model of Disability and the second is the Social Model of Disability. The medical model is individual-oriented, which, according to Oliver (2009) is explainable in two significant points:

Firstly, this model recognizes disability as a problem of disabled individuals. Secondly, it diagnoses the causes of the problems to be due to 
function limitations and psychological losses assumably arising from the individuals. Both points are supported by 'the personal tragedy theory of disability' which shows that disability is an accidental and horrible event that randomly occurs to an unlucky individual. Kristiansen et al. explained that the goal of this medical model is normalization. This implies that according to this model, disability should be recovered and returned to its normality (Kristiansen, Vehmas, \& Shakespeare 2009). Therefore, this model, according to Maftuhin (2017) only produces rehabilitative policies since disabled individuals are categorized as "sick" or "defective" which aims to 'normalize' or 'heal' the individuals from their disabilities. Furthermore, this perspective assumed that the function of intervention or treatment is to recover the disabled in order for them to positively participate in the structure of society (Stone-MacDonald \& Butera, 2014). Maftuhin (2017) also argued that the policies of government, through the ministry of social department are mostly influenced by this model, since intervention commonly includes medical rehabilitation and provision of social assistance (Mont, 2007).

The second is Social Model of Disability, which attempts to move the existing medical paradigm by shifting focus from individual to a more general discourse, namely social problem (Oliver, Sapey, \& Thomas 2012). Ro'fah (2015) stated that the problem of disability is broader and depends on an external factor, which is social environment and not on the consequence of an individual's physical or mental weaknesses. In line with this explanation, Kaplan Stone-MacDonald \& Butera (2014) also argued that social model regards disability as a normal aspect of life and not viewed as a violation. Briefly, the big idea of Social Model is when environmental accessibility is generally designed based on human's basic needs in order for the disabled not to encountered difficulties, i.e. to enable them holistically participate in the society (Mont, 2007). 
Furthermore, Social Model provides rights for the disabled since its main role is politicizing the issue of disability which provides them with the opportunity to speak up in the context or discourse of human right and citizenship arising right-based approach that now can be said as dominant hegemony in policy-making and service program for disability in both local and global discourses (Ro'fah, 2015).

\section{CONCLUSION AND SUGGESTION}

\section{Conclusion}

Today's social media platform has become embedded in society and has offered many different spaces to various groups, both to those with and without disabilities to engage, share information and communicate with others across the world. As a medium used by many globally, Instagram does not only play its role as a tool that can be used by all levels of society, but has also transformed into a very effective advocating tool for individuals and community of disabled.

In addition, as a social media it has become a networking platform that facilitates the basic needs of the disabled and provides space for them to earn their rights. This is evident from the availability of accounts which advertise job vacancies and freedom for the disabled to express their skills, passion and interests. More importantly, Instagram has been an effective advocacy tool for individuals or groups with disabilities to progressively improve their welfare and accessibility.

\section{Suggestion}

Based on the discoveries of this study, concrete action is needed when using Instagram as a social media, not just a medium for entertainment, but as a tool by all levels of society, to facilitate basic needs and provide space for rights for the disabled to express themselves. Furthermore, it is hoped that it will transform into an effective tool for advocating for individuals and groups with disabilities. 
For future studies, other methods such as the internet survey method, the method of phenomenology, grounded theories and exploration are needed to obtain complete and comprehensive discoveries related to the study of disability groups.

\section{REFERENCES}

Amin, B. (2019). Ulama-Difabel: Menarasikan Ekspresi Kultural Masyarakat Banjar dalam Lensa Studi Disabilitas. Khazanah: Jurnal Studi Islam Dan Humaniora, 17(2), 209-226. https://doi. org/10.18592/khazanah.v17i2.3215

Ananda S, M. (2018). Beradaptasi di Era Industri. Retrieved January 11, 2020, from kompasiana website: https://www.kompasiana. com/melynda25588/5b470217ab12ae455956c0a2/beradaptasidengan-era-disrupsi?page $=$ all

Azizah, N., \& Rahmatika, A. (2019). Korelasi Penggunaan Gadget Terhadap Kepuasan Komunikasi Interpersonal. Al-Balagh : Jurnal Dakwah Dan Komunikasi, 3(2), 211-234. https://doi.org/10.22515/ balagh.v3i2.1436

Caron, J., \& Light, J. (2016). "Social Media has Opened a World of 'Open communication:"” experiences of Adults with Cerebral Palsy who use Augmentative and Alternative Communication and Social Media. Augmentative and Alternative Communication, 32(1), 25-40. https://doi.org/10.3109/07434618.2015.1052887

Caton, S., \& Chapman, M. (2016). The Use of Social Media and People with Intellectual Disability: A systematic Review and Thematic Analysis. Journal of Intellectual and Developmental Disability, 41(2), 125-139. https://doi.org/10.3109/13668250.2016.1153052

Diana, C. (2012). Penggunaan Situs Jejaring Sosial Facebook Pada Remaja Disabilitas Intelegensi di Soina Rawamangun. Jurnal Pendidikan Khusus, Vol. 1(1), 98-106.

Ellis, K., \& Kent, M. (2011). Disability and New Media. Abingdon, United Kingdom: Routledge. 
Gleason, C., Carrington, P., Chilton, L. B., Gorman, B. M., Kacorri, H., Monroy-Hernández, A., Morris, M. R., Tigwell, G. W., \& Wu, S. (2019). Addressing the Accessibility of Social Media. Conference Companion Publication of the 2019 on Computer Supported Cooperative Work and Social Computing - CSCW '19, 474-479. https://doi. org/10.1145/3311957.3359439

Harahap, R. R. \& Bustanuddin. (2015). Perlindungan Hukum Terhadap Penyandang Disabilitas Menurut Convention On The Rights Of Persons With Disabilities (CRPD). Inovatif: Jurnal Ilmu Hukum, 8(1), 17-29.

Interview With Informant HN at 19 Desember 2019. (2019).

Interview With Informant MSN at 15 Desember 2019. (2019).

KBBI Online. (2020). Disrupsi. Retrieved January 11, 2020, from kbbi.web. id, website: https://www.kbbi.web.id/disrupsi

Kerjabilitas. (2020). Tentang. Retrieved January 16, 2020, from kerjabilitas. com website: https://kerjabilitas.com/main_page/kerj-about.php

Kristiansen, K., Vehmas, S., \& Shakespeare, T. (Eds.). (2009). Arguing About Disability: Philosophical Perspectives. Abingdon, United Kingdom: Routledge.

Maftuhin, A. (2017). Mendefinisikan Kota Inklusif: Asal-Usul, Teori dan Indikator. Tata Loka, 19(2), 93-103. https://doi.org/10.14710/ tataloka.19.2.93-103

Mamase, S., Mohidin, I., \& Hulopi, F. (2018). Aplikasi Media Komunikasi Bagi Penyandang Disabilitas Berbasis Android. JTII: Jurnal Teknologi Informasi Indonesia, 3(1), 7-11. https://doi.org/10.30869/ jtii.v3i1.180

Mayasari, A. (2018). Kisah Laninka Siamiyono, Difabel yang Merasa "Hidup Kembali" karena Makeup. Retrieved January 26, 2020, from detik.com website https://wolipop.detik.com/entertainmentnews/d-4141002/kisah-laninka-siamiyono-difabel-yang-merasahidup-kembali-karena-makeup

McMillen, R., \& Alter, F. (2017). Social Media, Social Inclusion, and Museum Disability Access. Museums \& Social Issues, 12(2), 115125. https://doi.org/10.1080/15596893.2017.1361689

Mont, D. (2007). Measuring Disability Prevalence. Washington DC, Unites States: World Bank.

Exploring Utilization of Instragram Platform as a Tool for Disability Advocacy

Ani Cahyadi, Agus Setiawan 
Morey, M. (2017). The Effects Of Social Media On The Quality Of Life Of People With Aphasia, The Honors College, 1-35.

Ningsih, Y. B. (2018). Angkie Yudistia Berdayakan Difabel Melalui Thisable Enterprise. Retrieved April 2, 2020, from tempo.co. website: https:/ / cantik.tempo.co/read/1083724/angkie-yudistia-berdayakandifabel-melalui-thisable-enterprise

Oliver, M. (2009). Understanding Disability: From Theory To Practice (2nd Ed.). London, United Kingdom: Red Globe Press. https://doi. org/10.1007/978-1-349-24269-6

Oliver, M., Sapey, B., \& Thomas, P. (2012). Social Work with Disabled People (4th ed). London, United Kingdom: Palgrave Macmillan.

Perwitasari, N. H. (2019). Profil Angkie Yudistia, Penyandang Disabilitas Staf Khusus Jokowi. Retrieved April 2, 2020, from tirto.id website: https://tirto.id/profil-angkie-yudistia-penyandang-disabilitasstaf-khusus-jokowi-el84

Rahmania, A. (2019). Retrieved January 2, 2020, from instagram wesbite: https://www.instagram.com/p/B4nxGOwgtrD/

Ro'fah. (2015). Teori Disabilitas: Sebuah Review Literatur. SIGAB: Jurnal Difabel, Vol 2(2), 137-160.

Rovasita, S. (2017). Sharing Experience dan Resiliensi: Studi atas Facebook Group Orang Tua Anak Cerebral Palsy. INKLUSI, 4(1), 119-148. https://doi.org/10.14421/ijds.040106

Salim, I. (2015a). Perspektif Difabilitas dalam Politik Indonesia. SIGAB: Jurnal Difabel, 2(2), 227-258.

Salim, I. (2015b). Perspektif Disabilitas dalam Pemilu 2014 dan Kontribusi Gerakan Difabel Indonesia bagi Terbangunnya Pemilu Inklusif di Indonesia, The POLITICS: Jurnal Magister Ilmu Politik Universitas Hasanuddin, 1(2), 127-156.

Saujana. (2020). Kerjabilitas. Retrieved January 16, 2020, from https:// saujana.org/wp/portfolio/kerjabilitas/

Siamiyono, L. (2020). Retrieved February 28, 2020, from instagram website: https://www.instagram.com/p/BraL8hHA7u8/

Stone-MacDonald, A., \& Butera, G. D. (2014). Cultural Beliefs and Attitudes about Disability in East Africa. Review of Disability Studies: An International Journal, 8(1). 
Sweet, K. S., LeBlanc, J. K., Stough, L. M., \& Sweany, N. W. (2020). Community Building and Knowledge Sharing by Individuals with Disabilities Using Social Media. Journal of Computer Assisted Learning, 36(1), 1-11. https://doi.org/10.1111/jcal.12377

This Able Enterprise. (2018). Tentang Thisable. Retrieved January 18, 2020, from thisable.or.id website: http://www.thisable.or.id/s/tentangthisable-26

Undang-Undang Republik Indonesia Nomor 8 Tahun 2016 Tentang Penyandang Disabilitas. (2016).

United Nations Human Rights Office The High Commisioner. (2018). Human rights of persons with disabilities. Retrieved November 20, 2018, from: ohchr.org wesbite: https://www.ohchr.org/en/ issues/disability/pages/disabilityindex.aspx 
Al-Balagh: Jurnal Dakwah dan Komunikasi,

Vol. 5, No. 2, July - December 2020, pp. 223 - 250, DOI: https://doi.org/10.22515/al-balagh.v5i2.2746 ISSN: 2527-5704 (P) ISSN: 2527-5682 (E) 